\title{
Kemampuan berpikir kritis siswa madrasah dalam pembelajaran matematika melalui model pembelajaran Problem based Learning (PBL) di Lembaga Pendidikan Islam
}

\author{
M. Habib Husnial Pardi ${ }^{*}$, Khafifaturrahmi2* \\ * Affiliasi: Universitas Islam Negeri Mataram
}

Keywords:
learning models,
Problem based learning,
critical thinking skills,
Madrasah
Tsanawiyah

Kata Kunci: model pembelajaran, problem based learning, kemampuan berpikir kritis, Madrasah sanawiyah

\begin{abstract}
A b s t r a c t: This study aims to determine the effect of the Problem based learning model on students' critical thinking skills at MTs Ittihadul Bayan. The research method used is an experiment with a quasi-experimental design, namely a nonequivalent control group design. Sampling was taken by purposive sampling with a sample of 20 students for the control class and 24 students for the experimental class. The data collection technique used a test technique with a test instrument in the form of a description. The hypothesis in this study is that there is an effect of the Problem based Learning model on students' critical thinking skills in MTs. Ittihadul Bayan. The data analysis used is the $\mathrm{t}$ test, from the two groups the $\mathrm{t}$ count value is 2.897 with a df of 42 and a significance level of $5 \%$ so that the $t$ table value is 1.681 so $2.897>1.681$. With the results of the data analysis, the hypothesis proposed in this study is $\mathrm{Ha}$ is accepted and $\mathrm{HO}$ is rejected, this shows that there is an effect of the Problem based Learning model on students' critical thinking skills in MTs Ittihadul Bayan.
\end{abstract}

A b s trak: Penelitian ini bertujuan untuk mengetahui pengaruh model pembelajaran problem based learning terhadap kemampuan berpikir kritis siswa di MTs Ittihadul Bayan. Metode penelitian yang digunakan adalah eksperimen dengan quasi experimental design yaitu nonequivalent control group design. Pengambilan sampel diambil dengan purposive sampling dengan jumlah sampel 20 siswa untuk kelas kontrol dan 24 siswa untuk kelas eksperimen. Teknik pengumpulan data menggunakan Teknik tes dengan instrument tes dalam bentuk uraian. Hipotesis pada penelitian ini adalah terdapat pengaruh model pembelajaran Problem based Learning terhadap kemampuan berpikir kritis siswa di MTs. Ittihadul Bayan. Adapun analisis data yang digunakan adalah $\mathrm{Uji}$ t, dari kedua kelompok tersebut diperoleh nilai $t$ hitung sebesar 2,897 dengan df 42 dan taraf signifikansi 5\% sehingga nilai $\mathrm{t}$ tabel sebesar 1,681 maka 2,897>1,681. Dengan hasil analisis data tersebut maka hipotesis diajukan dalam penelitian ini adalah $\mathrm{Ha}$ diterima dan $\mathrm{H} 0$

\footnotetext{
${ }^{1}$ Coresponden to author: Fakultas Tarbiyah dan Keguruan, Universitas Islam Negeri Mataram, Jl. Gajah Mada Jempong, Indonesia. (83116), e-mail addresses: mubhabib71@uinmataram.ac.id,

${ }^{2}$ E-mail addresses: k.hafifo122@gmail.com
}

M. Habib Husnial Pardi, Khafifaturrahmi (2021), Kemampuan berpikir kritis siswa..... 
ditolak, hal ini menunjukkan bahwa terdapat pengaruh model pembelajaran problem based learning terhadap kemampuan berpikir kritis siswa di MTs. Ittihadul Bayan.

\section{Article Info}

Article History: Received 01 Agustus 2021 | Revised 15 Agustus 2021|Accepted 12 September 2021 | Available online 20 September 2021

\section{Pendahuluan}

Berpikir kritis adalah kemampuan untuk bertanya dan/atau menjawab pertanyaan yang mendalam dengan cara yang paling produktif untuk mencapai pemahaman yang komprehensif (Hilsdon, 20103). Ini terdiri dari interpretasi, analisis, evaluasi, sintesis penjelasan, inferensi, dan pengaturan diri. Pemberdayaan keterampilan berpikir kritis di kalangan mahasiswa di perguruan tinggi khususnya dalam penulisan akademik melalui integrasi berpikir kritis ke dalam proses belajar mengajar sangat penting untuk mengembangkan keterampilan pemecahan masalah, pengambilan keputusan, dan komunikasi siswa (Abdullah, 20144; Adege, 20165; McLean, 20056). Pembelajaran berbasis inkuiri berkembang kemampuan berpikir kritis siswa karena membantu siswa mengembangkan interpretasi, analisis, mengevaluasi, menyimpulkan, menjelaskan, dan keterampilan pengaturan diri yang merupakan keterampilan berpikir kritis inti (Facione, 20117; Facione \& Facione, 19948; Hilsdon, 20109).

Tingkat berpikir tergantung pada tingkat bertanya asalkan bertanya mengarah pada perspektif baru (Buranapatana, 200610). Ketika siswa belajar untuk bertanya pada diri mereka sendiri pertanyaan yang menggugah pikiran di dalam dan di luar kelas, dan memberikan penjelasan jawaban, mereka baik di jalan untuk pengaturan diri belajar mereka. Dalam pertanyaan berbasis Kemampuan berpikir kritis pada matematika sangat penting bagi siswa karena dengan kemampuan ini siswa mampu bersikap rasional dan memilih alternatif pilihan yang terbaik bagi dirinya. Selain itu menanamkan kebiasaan berpikir kritis bagi siswa juga perlu

${ }^{3}$ Hilsdon, J. (2010). Critical thinking. Learning development with Plymouth University. Retrieved from: http://www.plymouth.ac. uk/learn

${ }^{4}$ Abdullah, T. (2014). Developing critical thinking skills through writing in an internet-based environment. International Journal of Humanities and Social Science, 4(1), 169-78

${ }^{5}$ Adege, A. (2016). The effects of explicit instruction in critical thinking on student achievement in writing academic papers, general critical thinking ability, and critical thinking dispositions. [doctoral dissertation]. Addis Ababa University

${ }^{6}$ McLean, C. (2005). Evaluating critical thinking skills: two conceptualizations. The Journal of Distance Education., 20(2), 1-20

${ }^{7}$ Facione, P.A. (2015). Critical thinking: what it is and why it counts, from APA report: Expert consensus statement on critical thinking.

${ }^{8}$ Facione, P., \& Facione, N. (1994). Holistic critical thinking scoring rubric. Santa Clara: Santa Clara Universit

${ }^{9}$ Hilsdon, J. (2010). Critical thinking ....Cop. Cit,

${ }^{10}$ Buranapatana, M. (2006). Enhancing critical thinking of undergraduate Thai students through dialogic inquiry. Doctoral dissertation. Australia: Canberra University

M. Habib Husnial Pardi, Khafifaturrahmi (2021), Kemampuan berpikir kritis siswa.....

Vol. 01. No. 02, $2021 \mid$ h. 89 
dilakukan agar mereka dapat mencermati berbagai persoalan yang terjadi dalam kehidupan sehari-hari.11 Sebuah studi internasional pada tahun 2011 dalam bidang matematika dan sains, Trend In International Mathematics and Science Study (TIMSS) untuk sekolah menengah pertama (SMP) menunjukkan bukti bahwa soal-soal matematika yang memerlukan berpikir kritis tidak rutin dijawab dengan benar oleh sampel siswa yang mengikuti studi tersebut atau bisa dikatakan bahwa nilai rata-rata kemampuan berpikir kritis siswa SMP kurang dari skor ideal ${ }^{12}$

Rendahnya kemampuan berpikir kritis yang menghasilkan kreativitas dalam beraktivitas siswa tersebut bisa saja disebabkan oleh berbagai faktor, salah satu diantaranya ialah pembelajaran yang berpusat pada guru (teacher centered). Dimana dalam strategi pembelajaran ini menekankan pada proses penyampaian materi secara verbal dari seorang guru kepada siswa. Strategi pembelajaran ini merupakan bentuk dari pendekatan pembelajaran yang berorientasi kepada guru yang dalam hal ini guru memegang peranan yang sangat penting atau peran guru lebih dominan sehingga siswa cenderung pasif ${ }^{13}$. Agar siswa memiliki kemampuan berpikir kritis maka pola pembelajaran dari pembelajaran yang berpusat pada guru (teacher centered) perlu diubah menjadi pembelajaran yang berpusat pada siswa (student centered). Pembelajaran yang berpusat pada siswa ini (student centered) dianggap lebih sesuai dengan kondisi eksternal saat ini yang menjadi tantangan bagi siswa untuk dapat mengambil keputusan secara efektif terhadap problematika yang dihadapinya. Melalui studentcentered learning siswa dituntut berpartisipasi secara aktif, ditantang untuk memiliki daya kritis, mampu menganalisis dan dapat memecahkan masalah-masalahnya sendiri ${ }^{14}$.

Salah satu upaya yang mungkin perlu dilakukan oleh seorang guru dalam peningkatan kemampuan berpikir kritis siswa, yaitu dengan menggunakan metode yang sesuai dengan materi dan tujuan pembelajaran. Dalam hal ini model Problem based learning (PBL) dinilai tepat digunakan dalam peningkatan kemampuan berpikir kritis siswa karena Problem based learning (PBL) juga termasuk dalam pola pembelajaran student centered yang menekankan siswa untuk berperan aktif dengan diberikan suatu permasalahan pada awal pembelajarannya yang bertujuan untuk Menyusun pengetahuan siswa, melatih kemandirian dan percaya diri, juga mengembangkan keterampilan berpikir siswa dalam pemecahan masalah.

Berdasarkan analisis awal dokumentasi hasil lembar jawaban siswa pada saat ujian semester ganjil di MTs Ittihadul Bayan menunjukkan bahwa soal-soal dalam bentuk uraian jarang dijawab oleh siswa kelas VIII, hanya sedikit siswa yang menjawab, namun jawabannya masih ada yang kurang tepat. Hanya sebagian kecil dari mereka yang memberikan jawaban yang

${ }^{11}$ T. Jumaisyaroh, E. E. Napitupulu, dan Hasratuddin, "Peningkatan kemampuan berpikir kritis matematis dan kemandirian belajar siswa SMP melalui pembelajaran berbasis masalah", Kreano, Vol. 5, No. 2, diakses pada tanggal 20 Desember 2014, hlm. 158.

12 Mega Achdisty Noordiana, "meningkatkan kemampuan berpikir kritis matematis siswa melalui pendekatan metacognitive instruction”, Mosharafa, Vol. 5, No. 2, mei 2016, hlm. 221

${ }^{13}$ Nandang Kosasih dan Dede Sumarna, Pembelajaran Quantum dan optimalisasi kecerdasan, (Bandung: Alfabeta, 2013), hlm. 54.

${ }^{14} \mathrm{Ibid}, \mathrm{hlm} .51$.

M. Habib Husnial Pardi, Khafifaturrahmi (2021), Kemampuan berpikir kritis siswa.....

Vol. 01. No. 02, 2021 | h. 90 
benar akan tetapi tidak disertai dengan langkah penyelesainnya. Dari beberapa indikator berpikir kritis yaitu: menganaisis dan mengklarifikasi suatu pertanyaan; mengidentifikasi dan mengevaluasi asumsi yang ada; menyusun klarifikasi dengan pertimbangan yang bernilai; memberikan penjelasan; memberikan simpulan dan argument, siswa hanya mampu menganaisis dan mengklarifikasi suatu pertanyaan saja. Berdasarkan latar belakang di atas, peneliti tertarik untuk mengetahui pengaruh model Problem Based Learning (PBL) terhadap kemampuan berpikir kritis siswa di MTs. Ittihadul Bayan dimana sekolah tersebut dalam pembelajarannya guru matematika masih menggunakan motode konvensional atau pembelajarannya masih berpusat pada guru. Karena itu rumusan pertanyaan yang diajukan dalam penelitian ini adalah "apakah penerapan model Problem based learning (PBL) memiliki pengaruh terhadap kemampuan berpikir kritis siswa kelas VIII di di lembaga pendidikan Islam: MTs Ittihadul Bayan?

\section{Kajian Literature}

Pembelajaran model Problem Based Solving (PBL) dapat mengembangkan keterampilan berpikir kritis siswa karena metode ini meningkatkan aktivitas mental siswa seperti interpretasi, analisis, evaluasi, penjelasan, inferensi, dan pengaturan diri. Studi sebelumnya telah menunjukkan bahwa siswa kemampuan berpikir kritis secara signifikan lebih tinggi ketika siswa diajar melalui pembelajaran berbasis Problem based learning (PBL) atau inkuiri dibandingkan dengan metode pengajaran tradisional. Rasa ingin tahu dalam mencari solusi merupakan metode pembelajaran yang lebih disukai daripada tindakan mengajar yang bercirikan pengajaran dengan paksaan (Ahmad, Sitti, Abdul, Mohammad, \& Sanitah, 2014; Iakovos, 2011). Dengan menggunakan pembelajaran berbasis solving atau inkuiri dalam pelajaran menulis, siswa dapat mengembangkan keterampilan berpikir kritis, dan belajar bagaimana menghasilkan dan mengatur ide-ide melalui penyelidikan atau/dan diskusi untuk menemukan ide-ide alternatif, dan menghasilkan karya tulis yang baik. Dengan demikian, siswa yang menggunakan teknik pembelajaran berbasis inkuiri dalam pembelajaran bahasa mereka berprestasi lebih baik karena mereka memiliki peran aktif dalam memilih topik tulisan, dan mengembangkan hasil penyelidikan mereka sendiri. Pembelajaran berbasis inkuiri memiliki dampak di kelas PBL untuk membantu siswa meningkatkan bahasa target, dan mengembangkan lainnya kemampuan yang dibutuhkan untuk memahami dunia yang terus berubah ini. Ketika siswa berpartisipasi dalam situasi kehidupan nyata, mereka dapat mengembangkan keterampilan penelitian yang efektif, beradaptasi dan merespon lebih baik untuk berubah, dan mereka juga siap untuk pengembangan keterampilan berpikir kritis (Escalante, 2013; Ismail, 2006; Lessner \& Craig, 2010). Penelitian serupa dilakukan oleh Ash dan Kluger-Bell (2012); Byker, Harden, Heafner, dan Holzberg (2017); Ahmad dkk. (2014) menemukan bahwa peserta didik lebih menyukai dan tampil jauh lebih baik dengan tingkat konfirmasi inkuiri dibandingkan dengan inkuiri terbimbing, terstruktur dan terbuka karena guru menyediakan setiap kondisi yang diperlukan dan memberikan kebebasan kepada siswa untuk belajar secara mandiri di tingkat konfirmasi.

M. Habib Husnial Pardi, Khafifaturrahmi (2021), Kemampuan berpikir kritis siswa.....

Vol. 01. No. 02, $2021 \mid$ h. 91 
Adapun sintaks pelaksanaan pembelajaran model Problem based learning menurut Arends dan Kilcher (2010) ${ }^{15}$ sebagai berikut:

\begin{tabular}{|c|c|c|}
\hline Fase & Kegiatan Guru & Kegiatan Siswa \\
\hline $\begin{array}{l}\text { Fase } 1 \\
\text { Orientasi siswa } \\
\text { Pada masalah }\end{array}$ & $\begin{array}{l}\text { Menjelaskan tujuan pembelajaran, } \\
\text { menjelaskan logistik yang } \\
\text { dibutuhkan } \\
\text { Memotivasi siswa terlibat aktif } \\
\text { dalam pemecahan masalah yang } \\
\text { dipilih }\end{array}$ & $\begin{array}{l}\text { Siswa mencatat dan mempersiapkan } \\
\text { kebutuhan yang diperlukan dalam } \\
\text { proses pembelajaran dan berada } \\
\text { dalam } \\
\text { kelompok yang telah ditetapkan }\end{array}$ \\
\hline $\begin{array}{l}\text { Fase } 2 \\
\text { Mengorganisasi } \\
\text { siswa }\end{array}$ & $\begin{array}{l}\text { Membantu siswa mendefinisikan } \\
\text { dan mengorganisasikan tugas } \\
\text { belajar yang berhubungan dengan } \\
\text { masalah tersebut }\end{array}$ & $\begin{array}{l}\text { Siswa membatasi permasalahan yang } \\
\text { akan dikaji }\end{array}$ \\
\hline $\begin{array}{l}\text { Fase } 3 \\
\text { Membimbing } \\
\text { penyelidikan } \\
\text { individual atau } \\
\text { kelompok }\end{array}$ & $\begin{array}{l}\text { Mendorong siswa untuk } \\
\text { mengumpulkan informasi yang } \\
\text { sesuai, melaksanakan } \\
\text { eksperimen untuk mendapatkan } \\
\text { penjelasan dan pemecahan } \\
\text { masalah }\end{array}$ & $\begin{array}{l}\text { Siswa mencari tahu, menginvestigasi, } \\
\text { dan bertanya untuk mendapatkan } \\
\text { jawaban atas permasalahan yang } \\
\text { dihadapi. }\end{array}$ \\
\hline $\begin{array}{l}\text { Fase } 4 \\
\text { Mengembangkan } \\
\text { dan menyajikan } \\
\text { hasil karya }\end{array}$ & $\begin{array}{l}\text { Membantu siswa dalam } \\
\text { merencanakan dan menyiapkan } \\
\text { karya yang sesuai seperti } \\
\text { laporan, model, dan berbagi tugas } \\
\text { dengan teman }\end{array}$ & $\begin{array}{l}\text { Siswa Menyusun laporan dalam } \\
\text { kelompok dan menyajikannya di } \\
\text { depan kelas dan berdiskusi dalam } \\
\text { kelas }\end{array}$ \\
\hline $\begin{array}{l}\text { Fase } 5 \\
\text { Menganalisa dan } \\
\text { mengevaluasi } \\
\text { proses pemecahan } \\
\text { masalah }\end{array}$ & $\begin{array}{l}\text { Mengevaluasi hasil belajar tentang } \\
\text { materi yang telah } \\
\text { dipelajari/meminta kelompok } \\
\text { presentasi hasil karya }\end{array}$ & $\begin{array}{l}\text { Siswa mengikuti tes dan } \\
\text { menyerahkan tugas-tugas sebagai } \\
\text { bahan evaluasi proses belajar }\end{array}$ \\
\hline
\end{tabular}

Berpikir kritis memainkan peran penting bagi siswa dalam kegiatan pembelajaran di kelas (Klimova, 2013; Ghaemi \& Mirsaed, 2017). Namun, berbagai penelitian dilakukan terhadap kemampuan berpikir kritis siswa dan kinerja menulis mengungkapkan bahwa siswa umumnya ditantang untuk mendukung argumen melalui merujuk dan mensintesis sumber akademik karena alasan yang buruk dan klaim yang tidak didukung. Terutama, mensintesis sumber adalah tugas yang kompleks untuk kedua dan pembelajar bahasa asing untuk memahami, memparafrase, dan meringkas teks tertulis (Alagozlu, 2007; Goodwin, 2014). Mengevaluasi dan mensintesis sumber ke dalam tulisan mereka sendiri adalah elemen berpikir kritis yang siswa temukan menantang untuk mengekspresikan diri mereka sendiri pemikiran akademis (Ahmad et al., 2014; Melles, 2009; Wette, 2010). Membina keterampilan berpikir kritis adalah tugas yang menantang saat ini karena peserta didik dihadapkan pada arus informasi yang sangat besar,

15 Arends, R. I., \& Klicher, A., 2010. Teaching for student learning becoming on accomplished teacher. Madison Avenue: Routledge Taylor and Francis Group.

M. Habib Husnial Pardi, Khafifaturrahmi (2021), Kemampuan berpikir kritis siswa.....

Vol. 01. No. 02, $2021 \mid$ h. 92 
seperti Internet (Klimova, 2013). Mereka ditawari potongan ide dan pendapat yang sudah dikunyah sebelumnya dan seringkali, mereka tidak dibuat untuk berpikir tentang mereka. Namun, seorang pemikir kritis harus waspada dan dalam sifatnya yang ingin tahu menanyakan, menilai dan mengevaluasi semua sumber tersebut secara kritis. Oleh karena itu, menggunakan pembelajaran berbasis inkuiri di kelas menulis sangat membantu untuk menumbuhkan keterampilan berpikir kritis siswa.

Paul and Elder (2007) menyatakan bahwa cara pengajaran konvensional, pendekatan produk, dikritik karena tidak mampu mempersiapkan lulusan universitas untuk menghadapi situasi kompleks yang ada, karena siswa diasumsikan mengembangkan keterampilan berpikir kritis. tergantung pada buku, catatan kuliah, dan handout. Hal ini juga menyebabkan siswa belajar dengan kurang minat pada topik, menerima daripada berpikir kritis dan mencari pengetahuan. Itu siswa sebagian besar tidak termotivasi untuk mengamati lingkungan mereka secara kritis, bertanya, sesuatu, menyelidiki masalah, dan menciptakan pengetahuan baru (Ferris \& Hedgcock, 2013; Graham, MacArthur, \& Fitzgerald, 2013; Yen, 2014). Namun, dalam situasi belajar seperti pembelajaran berbasis Problem Based Learning dan inquiry di mana pemikiran kritis ditekankan, dan siswa bertujuan untuk memahami ide-ide dengan berbagai eksplorasi dan mengikuti petunjuk baru; belajar dengan rasa ingin tahu atau minat topik, dan mencapai implikasi.

Adapun indicator seseorang yang memiliki kemampuan berpikir kritis sebagai berikut:

\begin{tabular}{|c|c|c|}
\hline No & Indikator & Deskripsi \\
\hline 1 & $\begin{array}{l}\text { Menganalisis dan mengklarifikasi } \\
\text { suatu pertanyaan }\end{array}$ & $\begin{array}{l}\text { Siswa mampu membedakan dan menjelaskan } \\
\text { pertanyaan dari suatu masalah. }\end{array}$ \\
\hline 2 & $\begin{array}{l}\text { Mengidentifikasi dan mengevaluasi } \\
\text { asumsi yang ada }\end{array}$ & $\begin{array}{l}\text { Siswa mampu menentukan langkah yang akan } \\
\text { digunakan dalam menyelesaikan masalah }\end{array}$ \\
\hline 3 & $\begin{array}{l}\text { Menyusun klarifikasi dengan } \\
\text { pertimbangan yang bernilai }\end{array}$ & $\begin{array}{l}\text { Siswa mampu menyusun langkah penyelesaian } \\
\text { dari suatu masalah atau mampu menerapkan } \\
\text { langkah yang telah ditentukan dalam } \\
\text { menyelesaikan suatu } \\
\text { masalah. }\end{array}$ \\
\hline 4 & Memberikan penjelasan & Siswa mampu menjelaskan suatu masalah \\
\hline 5 & Memberikan simpulan dan argument & $\begin{array}{l}\text { Siswa mampu memberikan kesimpulan dan } \\
\text { mampu memberikan argumen dari suatu } \\
\text { masalah. }\end{array}$ \\
\hline
\end{tabular}

\section{Metode}

Penelitian ini menggunakan pendekatan penelitian kuantitatif jenis eksprimen. Dengan memilih quasi experimental design yaitu adanya kelas eksperimen dan kelas control yang diberikan pree test untuk mengetahui keseimbangan kemampuan berpikir kritis antara kedua kelompok tersebut, selanjutnya kelas eksperimen Xa diberikan (treatment) menggunakan PBL dan kelas kontol tidak diberi perlakuan $\mathrm{X}_{\mathrm{b}}$ menggunakan metode pembelajaran konvesional.

M. Habib Husnial Pardi, Khafifaturrahmi (2021), Kemampuan berpikir kritis siswa.....

Vol. 01. No. 02, 2021 | h. 93 


\begin{tabular}{lccc}
\hline Kelas eksperimen: & O1 & Xa & O2 \\
VIII A: 20 & & & \\
Kelas control: VIII B: & O1 & Xb & O2 \\
24 & & & \\
\hline
\end{tabular}

\author{
Keterangan. \\ $\mathrm{O} 1=$ pretest (tes awal sebelum diberi perlakukan) \\ $\mathrm{O} 2=$ posttest (tes setelah diberi perlakukan) \\ $\mathrm{Xa}=$ diberikan perlakuan dengan menggunakan model pembelajaran problem based learnig. \\ $\mathrm{Xb}=$ diberikan perlakuan dengan menggunakan metode konvensional
}

Data dikumpulkan menggunakan Teknik tes dan dokumentasi. Adapun Teknik sampling menggunakan purposive sampling. Sedangkan analisis data dilakukan melalui beberapa tahap yaitu Uji keseimbangan, uji prasyarat. Uji homogenitas, dan uji hipotesis.

\title{
Hasil dan Pembahasan
}

Penelitian ini dilakukan salah satu lembaga pendidikan Islam swasta tepatnya di MTs Ittihadul Bayan Kecamatan Sekotong Kabupaten Lombok Barat yang berlangsung selama tiga minggu setelah peneliti mendapatkan izin dari Kepala Madrasah. Selama proses penelitian, peneliti diberikan kesempatan penuh selama jam pelajaran pertama sampai terakhir. penelitian eksprimen ini dilakukan sebanyak enam kali pertemuan, pertemuan pertama untuk pemberian Pree Test kepada kelas kontrol dan kelas eksperimen, pertemuan ke dua sampai dengan pertemuan ke lima dilakukan pembelajaran dengan menggunakan model pembelajaran Problem Based Learning untuk kelas eksperimen. Sedangkan kelas kontrol menggunakan metode konvensional dengan materi yang sama, dan pertemuan terakhir yaitu pemberian post tes untuk mengukur kemampuan berpikir kritis siswa setelah diberikan perlakuan. Selama penelitian berlangsung, pembelajaran berlangsung sesuai dengan planning yang telah dibuat, karena itu hamper tidak ditemukan hambatan atau kendala yang mengganggu proses pembelajaran. Pada kelas eksperimen yang diberikan perlakuan dengan menggunakan model pembelajaran Problem based learning (PBL) berlangsung sesuai dengan langkah-langkah dalam proses pembelajaran Problem based learning (PBL) yang telah ditetapkan yaitu pada awal pembelajaran siswa diberikan permasalahan yang harus di selesaikan. Siswa terlihat lebih aktif dan bersemangat dalam mencari solusi dari permasalahan yang diberikan. Berikut data hasil penelitian di table di bawah ini:

M. Habib Husnial Pardi, Khafifaturrahmi (2021), Kemampuan berpikir kritis siswa.....

Vol. 01. No. 02, 2021 | h. 94 


\begin{tabular}{cccccccc}
\hline No & $\mathbf{X}$ & $\mathbf{F}$ & $\mathbf{F}$ kum & $\mathbf{Z i}$ & $\mathbf{F}(\mathbf{Z i})$ & $\mathbf{S}(\mathbf{Z i})$ & $\mathbf{F}(\mathbf{Z I} \mathbf{- S}(\mathbf{Z I})$ \\
\hline 1 & 40 & 1 & 1 & -1.8303 & 0.0336 & 0.05 & 0.0164 \\
2 & 40 & 1 & 2 & -1.8303 & 0.0336 & 0.1 & 0.0664 \\
3 & 44 & 1 & 3 & -1.4945 & 0.0681 & 0.15 & 0.0819 \\
4 & 52 & 1 & 4 & -0.8228 & 0.2061 & 0.2 & 0.0061 \\
5 & 52 & 1 & 5 & -0.8228 & 0.2061 & 0.25 & 0.0439 \\
6 & 54 & 1 & 6 & -0.6549 & 0.2578 & 0.3 & 0.0422 \\
7 & 54 & 1 & 7 & -0.6549 & 0.2578 & 0.35 & 0.0922 \\
8 & 60 & 1 & 8 & -0.1511 & 0.4404 & 0.4 & 0.0404 \\
9 & 62 & 1 & 9 & 0.0167 & 0.504 & 0.45 & 0.054 \\
10 & 62 & 1 & 10 & 0.0167 & 0.504 & 0.5 & 0.004 \\
11 & 64 & 1 & 11 & 0.1847 & 0.5714 & 0.56 & 0.0214 \\
12 & 66 & 1 & 12 & 0.3526 & 0.6368 & 0.6 & 0.0368 \\
13 & 70 & 1 & 13 & 0.6884 & 0.7517 & 0.65 & 0.1017 \\
14 & 70 & 1 & 14 & 0.6884 & 0.7517 & 0.7 & 0.0517 \\
15 & 72 & 1 & 15 & 0.8564 & 0.8023 & 0.75 & 0.0523 \\
16 & 74 & 1 & 16 & 1.0243 & 0.88461 & 0.8 & 0.0461 \\
17 & 74 & 1 & 17 & 1.0243 & 0.8461 & 0.85 & 0.0039 \\
18 & 74 & 1 & 18 & 1.0243 & 0.8461 & 0.9 & 0.0539 \\
19 & 76 & 1 & 19 & 1.1922 & 0.883 & 0.95 & 0.067 \\
20 & 76 & 1 & 20 & 1.1922 & 0.883 & 1 & 0.117 \\
\hline Rata-rata & $\mathbf{6 2 . 0 9}$ & $\mathbf{1 . 1 7 0 2}$ & $\mathbf{L ~ M a k s}$ & $\mathbf{0 . 1 1 7}$ & & L. Maks & $\mathbf{0 . 1 1 7}$ \\
\hline
\end{tabular}

Dari Uji keseimbangan kelas eksperimen dan kelas control Pada kelas eksperimen untuk pree test diketahui bahwa perolehan skor Free Test terendah adalah 44 dan skor pree test tertinggi adalah 76 dengan rata-rata 62,09, sedangkan untuk kelas kontrol perolehan skor free test terendah adalah 40 dan skor pree test tertinggi adalah 76 dengan rata-rata 62,8 sehingga selisih rata-rata antara kelas eksperimen dan kelas kontrol pada pree test ini adalah 0,71. Nilai rata-rata tersebut diperoleh dari jumlah keseluruhan skor yang diperoleh dibagi dengan jumlah sampel masing-masing kelompok. Uji normalitas pree test kelas eksperimen dan kelas control Uji normalitas untuk data pree test kelas control.

Selanjutnya uji hipotesis kelas eksperimen dan kelas control pada kelas eksperimen untuk Post Test diketahui bahwa perolehan skor terendah adalah 48 dan skor tertinggi adalah 84 dengan rata-rata 71,7, sedangkan untuk kelas kontrol perolehan skor terendah adalah 40 dan skor tertinggi adalah 76 dengan rata-rata 61,8 sehingga selisih rata-rata antara kelas eksperimen dan kelas kontrol pada Post Test ini adalah 9,9. Nilai rata-rata tersebut diperoleh dari jumlah keseluruhan skor yang diperoleh dibagi dengan jumlah sampel masing-masing kelompok.

Dari hasil uji hipotesis menggunakan uji t pada Post Test diperoleh nilai thitung sebesar 2,933 sedangkan ttabel dengan df 42 yang diperoleh dari jumlah sampel kelas eksperimen ditambah jumlah sampel kelas kontrol lalu dikurangi dua atau $\mathrm{df}=(24+20-2)=42$ maka 
ttabel sebesar 1,681. Karena thitung $(2,933)$ lebih besar dari ttabel $(1,684)$. Berdasarkan kriteria maka HO ditolak dan Ha diterima maka terdapat pengaruh model pembelajaran Problem based learning (PBL) terhadap kemampuan berpikir kritis siswa di MTs. Ittihadul Bayan.

Dari uraian diatas dapat disimpulkan bahwa menerapkan model pembelajaran Problem based learning (PBL) dapat berpengaruh terhadap kemampuan berpikir kritis siswa yaitu dengan membiasakan siswa terlibat lebih aktif dan memecahkan sendiri permasalahan-permasalahan yang diberikan. Pada dasarnya PBL berfokus pada pemberian masalah kepada siswa supaya siswa terbiasa dengan masalah-masalah yang diberikan dan mampu menyelesaikannya dengan tepat. Dengan diterapkannya PBL ini siswa menjadi lebih aktif dan terbiasa menyelesaikan masalah yang diberikan dan mampu bekerja sama dengan temantemannya agar mendapatkan solusi yang tepat dalam menyelesaikan masalah yang diberikan. Menurut Jumaisyaroh dkk mengatakan bahwa berpikir kritis merupakan dasar dari proses berpikir untuk menganalisis argumen dan memunculkan gagasan terhadap tiap makna untuk mengembangkan pola pikir secara logis ${ }^{16}$. Sesuai dengan pernyataan tersebut bahwa berpikir kritis begitu penting dan menjadi dasar dalam menganalisis argumen dan memperoleh gagasan yang bersifat logis.

Dengan berpikir kritis inilah siswa mampu menganalisis setiap permasalahan dan diterapkan agar mendapatkan gagasan yang tepat dan logis dalam menentukan solusi untuk setiap masalah yang dihadapi. Menurut Syutaridho dalam penelitiannya, Ia mengatakan bahwa kebiasaan berpikir kritis memberikan efek pada kecakapan seorang siswa atau berefek potensial terhadap hasil belajar siswa, dimana kecepatan dan ketepatan dalam menyelesaikan masalah matematika dan membiasakan kita berargumen atau berkomunikasi matematika dengan berbagai sudut pandang sesuai dengan konteks masalah ${ }^{17}$. Apabila siswa dibiasakan dalam mengolah kemampuan berpikir kritis maka semakin lama siswa akan terbiasa menyelesaikan masalah dengan cepat dan tepat karena siswa sudah terbiasa menyelesaikan masalah dengan memikirkan solusi secara logis akibat dari kebiasaan dalam berpikir kritis. Selain itu siswa juga terbiasa dalam menyampaikan argument dan mampu berkomunikasi dengan baik sehingga hasil belajar siswa akan menjadi lebih baik. Dalam penelitiannya Siti Nurkholifah dkk mengatakan bahwa dalam mengembangkan kemampuan matematika khususnya kemampuan berpikir kritis, seorang siswa harus memiliki sikap yakin atau percaya akan kemampuan sendiri sehingga terhindar dari rasa cemas dan ragu $^{18}$. Sesuai dengan pernyataan tersebut bahwa dalam mengembangkan kemampuan berpikir kritis, siswa harus memiliki keyakinan dan kepercayaan diri bahwa mereka mampu memecahkan permasalahan matematika yang diberikan. Dengan rasa

${ }^{16}$ T. Jumaisyaroh, E.E. Napitupulu, dan Hasratuddin, "Peningkatan kemampuan berpikir kritis matematis dan kemandirian belajar siswa SMP melalui pembelajaran berbasis masalab”, Kreano, Vol. 5, No. 2, hlm. 158.

${ }^{17}$ Syutaridho, "Mengontrol aktivitas berpikir kritis siswa dengan memunculkan soal berpikir kritis", JPM RAFA, Vol. 2, No. 1, 2016. Hlm. 34.

18 Siti Nurkholifah, Toheri, Widodo Winarso, "Hubungan antara self-confidence dengan kemampuan berpikir kritis siswa dalam pembelajaran matematika", Edumatica, Vol. 8, No. 1, April 2018, hlm. 59

M. Habib Husnial Pardi, Khafifaturrahmi (2021), Kemampuan berpikir kritis siswa.....

Vol. 01. No. 02, $2021 \mid$ h. 96 
percaya diri inilah siswa akan terdorong untuk mencoba dan mulai berpikir secara logis dalam menentukan solusi yang tepat untuk menyelesaikan permasalahan yang diberikan.

Kebanyakan siswa menganggap bahwa matematika itu sulit untuk dipecahkan sehingga mereka enggan untuk mencoba memecahkan sendiri permasalahan matematika yang diberikan. Begitu juga dengan siswa di MTs. Ittihadul Bayan, mereka merasa permasalahan matematika sulit untuk dipecahkan yang mengakibatkan tidak adanya rasa percaya diri terhadap kemampuan mereka dalam memecahkan masalah sehingga mereka enggan untuk mencoba memecahkan atau mencari solusi sendiri dari masalah matematika yang diberikan. Rasa tidak percaya diri ini terus dirasakan oleh siswa sehingga mereka terbiasa dan menjadi malas mencari penyelesaian sendiri dari permasalahan matematika yang diberikan. Setelah penelitian berlangsung dimana peneliti menggunakan model pembelajaran Problem based learning (PBL) dalam proses pembelajaran, dengan begitu siswa dituntut harus mampu memecahkan dan mencari solusi yang paling tepat untuk menyelesaikan permasalahan yang diberikan. Selain itu siswa juga harus memiliki rasa percaya diri dan yakin bahwa permasalahan tersebut dapat diselesaikan dengan tepat. Berlangsungnya peneelitian membuat rasa percaya diri mereka mulai muncul dan mau mencoba menyelesaikan permasalahan sendiri dengan berdiskusi bersama teman sekelompok mereka, hal ini terus terjadi sepanjang penelitian sehingga merekapun terbiasa menyelesaikan permasalahan sendiri dan terus ingin mencoba menyelesaikan sendiri permasalahan matematika yang diberikan.

Menurut Asria Hirda Yanti mengatakan bahwa memiliki kemampuan pemecahan masalah artinya siswa mampu memahami masalah, Menyusun rencana dalam pemecahan masalah, mampu menjalankan recana pemecahan masalah dan mampu meninjau kembali hasil pemecahan masalah tersebut. ${ }^{19}$ Kegiatan pembelajaran menggunakan model pembelajaran Problem Based Learning (PBL) mampu memotifasi siswa untuk mengembangkan kemampuan pemecahan masalah dan mengembangkan kemampuan berpikir kritis siswa, karena dengan PBL ini mengarahkan siswa agar berpikir secara mandiri dan mendalam untuk dapat memecahkan masalah matematika yang diberikan. Semakin sering siswa memecahkan sendiri permasalahan matematika maka akan semakin berkembang kemampuan berpikir kritis siswa, karena pada proses pemecahan masalah, siswa memerlukan kemampuan berpikir kritis untuk memikirkan secara mendalam dan logis solusi yang tepat dalam memecahkan permasalahan tersebut.

Pernyataan tersebut dibuktikan dari hasil uji hipotesis tentang pengaruh model pembelajaran Problem Based Learning (PBL) terhadap kemampuan berpikir kritis siswa, analisis Post Test nilai rata-rata kelas eksperimen sebesar 71,7 sedangkan nilai rata-rata kelas kontrol sebesar 61,8, kelas eksperimen lebih unggul 9,9. Nilai ini cukup membuktikan bahwa model pembelajaran PBL lebih baik dibandingkan model pembelajaran konvensional dalam

${ }^{19}$ Asria Hirda Yanti, "penerapan model problem based learning (PBL) terhadap kemampuan komunikasi dan kemampuan pemecahan masalah matematika siswa sekolah menengah pertama Lubuklinggau” Jurnal Pendidikan Matematika Raflesia, Vol. 2, No. 2, 2017, hlm. 127.

M. Habib Husnial Pardi, Khafifaturrahmi (2021), Kemampuan berpikir kritis siswa.....

Vol. 01. No. 02, 2021 | h. 97 
pengaruhnya terhadap kemampuan berpikir kritis siswa. Dari hasil uji hipotesis data Post Test menggunakan uji t untuk menghitung besar pengaruh model pembelajaran Problem Based Learning (PBL) terhadap kemampuan berpikir kritis siswa menunjukkan nilai t hitung sebesar 2,933 sedangkan t tabel sebesar 1,681 yang apabila t hitung lebih besar dari t tabel maka terdapat pengaruh model pembelajaran Problem Based Learning (PBL) terhadap kemampuan berpikir kritis siswa kelas VIII di lembaga pendidikan Islam: MTs. Ittihadul Bayan.

\section{Kesimpulan}

Hasil studi ini menyimpulkan bahwa ada pengaruh diterapkan model Problem Bases Learning (PBL) terhadap peningkatan kemampuan berpikir kritis siswa kelas VIII di lembaga Pendidikan Islam: MTs Ittihadul Bayan. Kesimpulan ini diukung oleh adanya selisih rata antara kelas ekspirmen dan kelas control yaitu 9.9 berdasarkan data hasil Post Test yaitu rata-rata data kelas eksperimen adalah 71,7, sedangkan untuk kelas kontrol 61,8. Sedangkan hasil uji hipotesis Post Test menunjukkan bahwa $\mathrm{t}$ hitung lebih besar dari $\mathrm{t}$ tabel yaitu terhitung $(2,933)>\mathrm{t}$-tabel $(1,681)$. Sesuai dengan hipotesis yang diajukan bahwa apabila $t$ hitung lebih besar dari t tabel maka $\mathrm{Ha}$ di terima dan $\mathrm{H} 0$ ditolak dengan hipotesis $\mathrm{H} 0=$ tidak terdapat pengaruh model pembelajaran Problem Based Learning (PBL) terhadap kemampuan berpikir kritis siswa di MTs. Ittihadul Bayan. $\mathrm{Ha}=$ terdapat pengaruh model pembelajaran Problem Based Learning (PBL) terhadap kemampuan berpikir kritis siswa di MTs Ittihadul Bayan.

\section{Referensi}

Abdullah, T. (2014). Developing critical thinking skills through writing in an internet-based environment. International Journal of Humanities and Social Science.

Adege, A. (2016). The effects of explicit instruction in critical thinking on student achievement in writing academic papers, general critical thinking ability, and critical thinking dispositions. [doctoral dissertation]. Addis Ababa University

Ahmad Zaeni, (2014) "Teknik pengukuran kemampuan berpikir kritis", link sumber: http/ / faqihzaeni.blogspot.com/2014/12/teknikpengukuran-kemampuan- berpikir.html?m=1, diakses tanggal 16 Desember 2014.

Ajeng Khusnul Huda, (2015) "Pengaruh penerapan Inkuiri terhadap kemampuan berpikir kritis dan basil belajar siswa SMA NU Al-Ma'ruf Kudus", skripsi, Universitas Negeri Semarang, Semarang

Akino'lu, O. \& R. O. Tando'an. (2007). The effects of Problem-Based Active Learning in Science Education on Students Academic Achievement, Attitude and Concept Learning. Eurasia Journal of Mathematics, Science \& Technology Education.

Asria Hirda Yanti, (2017), "Penerapan problem based learning terhadap kemampuan komunikasi dan kemampuan pemecahan masalah matematika siswa sekolah

M. Habib Husnial Pardi, Khafifaturrahmi (2021), Kemampuan berpikir kritis siswa.....

Vol. 01. No. 02, 2021 | h. 98 
menengah pertama lubuklinggau", Jurnal Pendidikan Matematika Raflesia, Vol. 2, Nomor 2, 2017

Buranapatana, M. (2006). Enhancing critical thinking of undergraduate Thai students through dialogic inquiry. Doctoral dissertation. Australia: Canberra University

Burris, S. \& Garton, B. L. (2007). Effect of Instructional Strategy on Critical Thinking and Content Knowledge: Using Problem-Based Learning in The Secondary Classroom. Journal of Agricultural Education Volume 48, Number 1, 2007

Donald Ary, Luchy Cheser Jacobs dan Asghar Razavieh, (2011) pengantar penelitian dalam pendidikan, terj. Arief Furchan, Yogyakarta: Pustaka Pelajar, cet. Ke-4.

Elsa Destriyani, (2016) "Peningkatan keterampilan berpikir kritis dan hasil belajar siswa melalui penerapan model discovery learning pada mata pelajaran matematika siswa kelas IV SD Negeri 1 Pujo Basuki tahun 2015/2016”, Skripsi, Universitas Lampung, Bandar Lampung

Fajrianthi, Wiwin Hendriani, dan Berlian Gressy Septarini, (2016) "pengembangkan tes berpikir kritis dengan pendekatan item response theory", Jurnal penelitian dan evaluasi pendidika, Vol. 20, No. 1, Juni 2016,

Facione, P.A. (2015). Critical thinking: what it is and why it counts, from APA report: Expert consensus statement on critical thinking.

Facione, P., \& Facione, N. (1994). Holistic critical thinking scoring rubric. Santa Clara: Santa Clara Universit

Hamruni, (2012), “Strstegi Pembelajaran, Yogyakarta: Insan Madani

Hilsdon, J. (2010). Critical thinking. Learning development with Plymouth University. Retrieved from: http://www.plymouth.ac. uk/learn

Ibrahim, (2017) "Perpaduan model pembelajaran aktif konvensional ceramah dengan Cooperatif make a match untuk meningkatkan hasil belajar pendidikan kewarganegaraan", suara Guru, Vol. 3, No. 2, Juni 2017.

Ika Rahmawati, Arif Hidayat dan Sri Rahayu, (2016) "Analisis keterampilan berpikir kritis siswa SMP pada materi gaya dan penerapannya”, Semnas, Vol. 2, 2016

Lilyan Rifqiyana, (2015) "Analisis kemampuan berpikir kritis siswa dengan pembelajaran model 4K materi geometri kelas VIII ditinjau dari gaya kognitif siswa”, Skripsi, Universitas Negeri Semarang, Semarang, 2015

Lumsdaine, E. \& M. Lumsdaine. (1995). "Creative Problem Solving Thinking Skills for Changing World”. Singapore: McGraw-Hill

Masek, A. dan Yamin, S. (2011). The Effect of Problem Based Learning on Critical Thinking Ability: A Theoretical and Empirical Review. International Review of Social Sciences and Humanities Vol.2, No.1 (2011)

McLean, C. (2005). Evaluating critical thinking skills: two conceptualizations. The Journal of Distance Education., 20(2)

M. Habib Husnial Pardi, Khafifaturrahmi (2021), Kemampuan berpikir kritis siswa.....

Vol. 01. No. 02, 2021 | h. 99 
Mega Achdisty Noordiana, (2016), "Meningkatkan kemampuan berpikir kritis matematis siswa melalui pendekatan metacognitive instruction", Mosharafa, Vol. 5, No. 2, mei 2016

Miftahul Huda, (2017) "Model-model Pengajaran dan Pembelajaran: Isu-isu Metodis dan Paradigmatis, Yogyakarta: Puataka Pelajar

Moh. Nazir, (2005), “Metode Penelitian”, Bogor: Ghalia Indonesia, cet. Ke-6.

Moore, B. \& T. Stanley. (2010). Critical Thinking \& Formative Assessments. New York: Eye On Education, Inc

Muhammad Fathurrohman, (2017), "Model-Model Pembelajaran Inovatif, Yogyakarta: Ar-Ruzz Media

Nanang Hanafiah dan Cucu Suhana, (2010), “Konsep strategi pembelajaran”, Bandung: PT Refika Adimata, cet. Ke-2.

Nandang Kosasih dan Dede Sumarna, (2013), "Pembelajaran Quantum dan optimalisasi Kecerdasan”, Bandung: Alfabeta

Peter, E. E. (2012). Critical thinking: Essence for Teaching Mathematics and Mathematics Problem Solving Skills. African Journal of Mathematics and Computer Science Research Vol. 5(3), Available online at http:/ / wnn. academicjoumals.org/AJMCSR

Purwanto, (2012), "Metodologi Penelitian Kuantitatif untuk Psikologi dan Pendidikan, Yogyakarta: Puataka Pelajar,, cet. Ke- 4.

Retnaning Tyas, (2017), "Kesulitan penerapan problem based learning dalam pembelajaran matematika", Tecnoscien₹a, Vol. 2 No. 1, Oktober 2017

Snyder, L. G. \& M. J. Snyder. (2008). Teaching Critical Thinking and Problem Solving Skills. The Delta Pi Epsilon Journal Volume L, No. 2, Spring/Summer, 2008

Siti Nurkholifah, Toheri, Widodo Winarso, (2018), "Hubungan antara self-confidence dengan kemampuan berpikir kritis siswa dalam pembelajaran matematika", Edumatica, Vol. 8, No. 1, April 2018

Sugiyono, (2014), “Metode penelitian kuantitatif kualitatif dan $\mathrm{R} \& \mathrm{D}$, Bandung: Alfabeta, cetakan ke-20.

Sutarto dan Syarifuddin, (2013), "Desain pembelajaran matematika, Yogyakarta: Penerbit Samudera Biru

Syutaridho, "Mengontrol aktivitas berpikir kritis siswa dengan memunculkan soal berpikir kritis”, Jurnal Pendidikan Matematika JPM RAFA, Vol. 2, No. 1,

T. Jumaisyaroh, E. E. Napitupulu, dan Hasratuddin, "Peningkatan kemampuan berpikir kritis matematis dan kemandirian belajar siswa SMP melalui pembelajaran berbasis masalah". Kreano, Vol. 5, No. 2, Desember 2014 